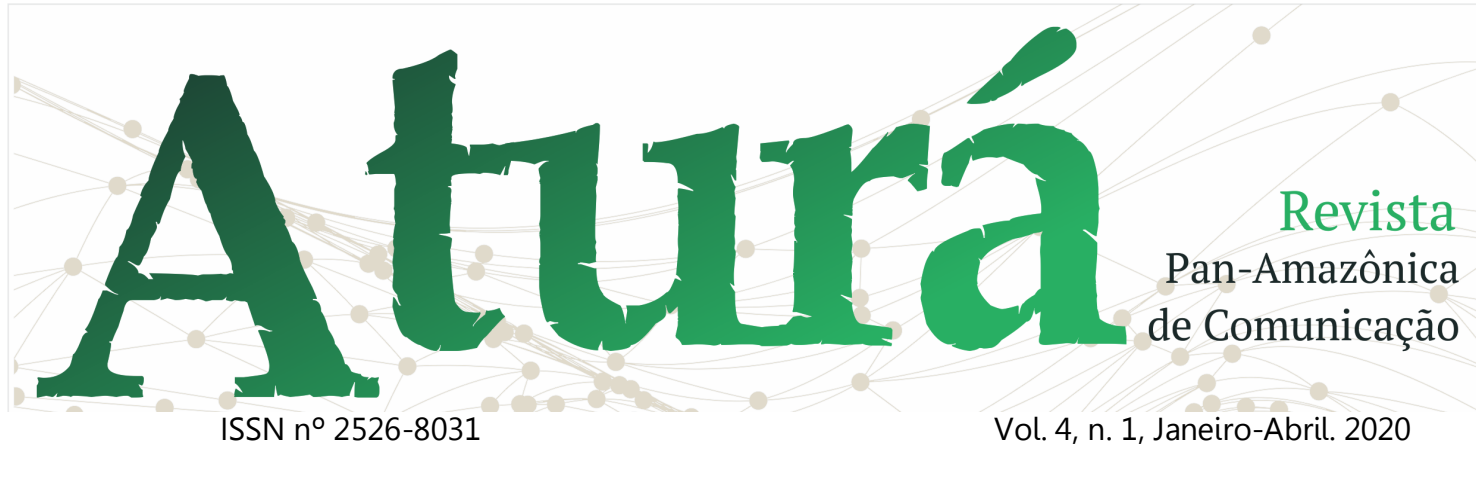

DOI: http://dx.doi.org/10.20873/uft.2526-8031.2020v4n1p182

\title{
ASSESSORIA DE IMPRENSA E O RELACIONAMENTO COM OS JORNALISTAS DE TV
}

PRESS ADVISORY AND RELATIONSHIP WITH TV JOURNALISTS

PRENSA Y RELACIÓN CON PERIODISTAS DE TV

\section{Clifton Morais Correia ${ }^{1}$ \\ Francisco Gilson Rebouças Porto Junior2, 3}

\section{RESUMO}

Esta pesquisa traz uma breve discussão sobre as expectativas dos assessorados sobre seus assessores no que se refere ao desenvolvimento de suas atividades, a ética e linha editorial de cada empresa, seja ela de assessoria ou das organizações dos jornais. A pesquisa foi desenvolvida abordando as características dos profissionais que desempenham as funções de assessor de imprensa e as de produtores de TV. Além disso, foi feita uma abordagem entre o significado de deadline, releases e como deve ser o relacionamento dos assessores com os profissionais de TV, relacionamento esse aliado às necessidades diárias de divulgação de informações o mais exatas possível.

\footnotetext{
${ }^{1}$ Graduado em Comunicação Social com habilitação em Jornalismo pela Universidade de Gurupi (UnirG). Especialista em Ensino de Comunicação/Jornalismo: Temas Contemporâneos, pela Universidade Federal do Tocantins (UFT). Especialista em Assessoria de Comunicação e Novas Tecnologias, pela Faculdade de Ciências Sociais Aplicadas de Marabá (FACIMAB). Mestrando em Comunicação e Sociedade pela Universidade Federal do Tocantins (UFT). E-mail: cliftonmorais@hotmail.com.

${ }^{2}$ Doutor em Comunicação e Cultura Contemporâneas pela Faculdade de Comunicação da Universidade Federal da Bahia (FACOM-UFBA), mestre em Educação pela Faculdade de Educação (PPGE-UnB) e graduado em Comunicação Social/Jornalismo, Pedagogia, História e Letras. Professor na Universidade Federal do Tocantins (UFT). E-mail: gilsonporto@uft.edu.br.

${ }^{3}$ Endereço de contato com os autores (por correio): Universidade Federal do Tocantins, OPAJE. Quadra 109 Norte, Avenida NS 15, Plano Diretor Norte, CEP: 77001090 - Palmas, TO - Brasil.
} 


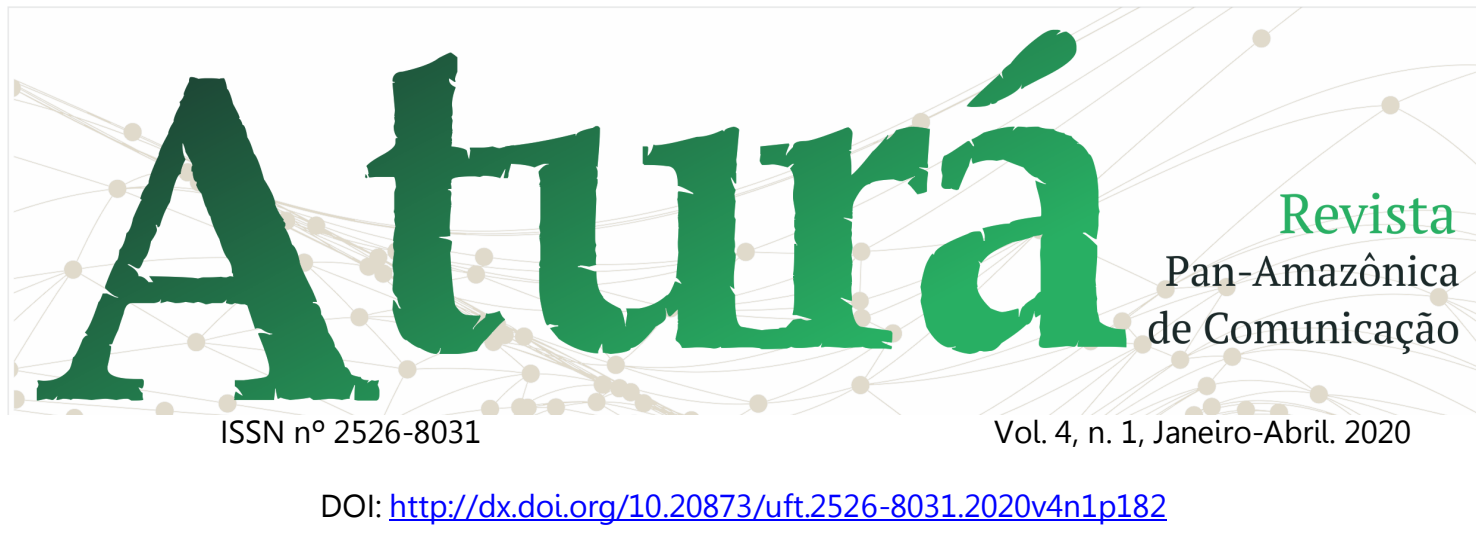

PALAVRAS-CHAVES: Jornalismo; Assessoria de Imprensa; Jornalistas; Empresas jornalísticas.

\begin{abstract}
This research brings a brief discussion about the expectations of the advisors about their advisors with regard to the development of their activities, the ethics and editorial line of each company, be it advisory or the organizations of newspapers. The research was developed addressing the characteristics of the professionals who perform the functions of press officer and those of TV producers. In addition, an approach was taken between the meaning of deadline, releases and how the relationship between advisors and TV professionals should be, a relationship that allied to the daily needs of disclosing information as accurately as possible.
\end{abstract}

KEYWORDS: Journalism; Press office; Journalists; Newspaper companies.

\title{
RESUMEN
}

Esta investigación trae una breve discusión sobre las expectativas de los asesores sobre sus asesores con respecto al desarrollo de sus actividades, la ética y la línea editorial de cada empresa, ya sea de asesoramiento u organizaciones de periódicos. La investigación se desarrolló abordando las características de los profesionales que desempeñan las funciones de responsable de prensa y las de los productores de televisión. Además, se adoptó un enfoque entre el significado de la fecha límite, los comunicados y cómo debería ser la relación entre asesores y profesionales de la televisión, una relación que se alió a las necesidades diarias de revelar información con la mayor precisión posible.

PALABRAS CLAVE: Periodismo; Oficina de prensa; Periodistas Compañías de periódicos.

Recebido em: 12.11.2019. Aceito em: 12.12.2019. Publicado em: 03.01.2020. 


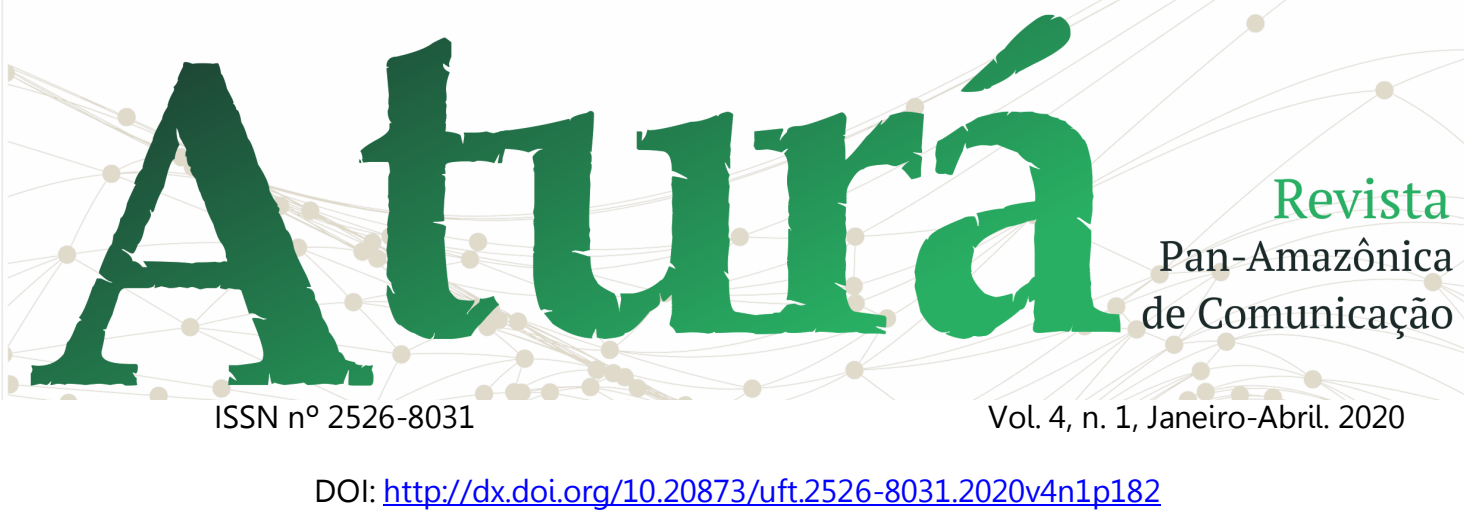

\section{INTRODUÇÃO}

A comunicação, em suas diferentes formas e sentidos, acompanha a sociedade desde os tempos mais primitivos. Comunicar ajuda, na mesma proporção e intensidade, a construir ou destruir imagens, estruturas e organismos.

$\mathrm{Na}$ comunicação, enquanto atividade, comunicar é a essência, ou seja, nas mais diversas atribuições que envolvem essa tarefa, a boa comunicação e o bom relacionamento tornam-se sinônimos de sucesso profissional no exercício efetivo da profissão (SEIXAS, 2018; ROCHA et al., 2018; ROSA et al., 2018; SANTOS; MARTINS, 2018; SILVA et al., 2017; SILVA; SARTORI; MARTINI， 2017; SILVEIRA JUNIOR, 2015; TEIXEIRA et al., 2017; VILAS BOAS; MUNIZ, 2018; TREVISAN, 2016). Essa atividade vem sendo modificada nas últimas décadas, acompanhando as transformações formativas mundiais (ALVES.; SILVA; SILVA, 2017; ANDREATTA-DA-COSTA; CASTILHOS, 2017; BAPTAGLIN; CHIERENTIN SANTI, 2018; EVANGELISTA et al., 2019; GALLERT; TACCA, 2016; LOPES; PEREIRA; MOURA; CARVALHO, 2015; LUCENA.; OLIVEIRA, 2019; MACHADO; COSTA; MORAES, 2018; ROCHA; NOGUEIRA,
2019; MELO, 2017; MIRANDA-PINTO et al., 2017; MOIO et al., 2017; MOTA; FERREIRA, 2017; NEIVA; AUGUSTO, 2015; NUNES; PORTO JUNIOR; MORAES, 2017; PINHO, 2017; PORTO JUNIOR; MORAES, 2017; REIS, 2017; MELO, 2017; MIRANDA-PINTO et al., 2017; MOIO et al., 2017; MOTA; FERREIRA, 2017; NEIVA; AUGUSTO, 2015; NUNES; PORTO JUNIOR; MORAES, 2017; PINHO, 2017; PORTO JUNIOR; MORAES, 2017; REIS, 2017; MARTINEZ, 2016).

Entre as atividades mais importantes relacionadas à comunicação está a da assessoria de imprensa. Esta precisa trabalhar incansavelmente para criar e/ou manter a boa imagem de quem the paga pelos serviços, e isso só se obtém com disciplina, rigor, agilidade, trabalho sistematizado e bons contatos com as redações.

Para os profissionais que atuam nas redações não é diferente. $O$ trabalho árduo e a correria do dia a dia fazem com que repórteres e produtores se voltem para a prática tendenciosa de serem alimentados pelos assessores para manter seus programas jornalísticos abastecidos de notícias. Estes dois polos se encontram e se relacionam todos os 


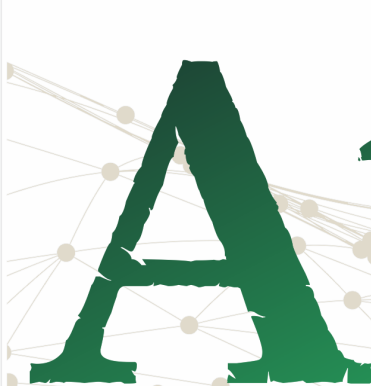

ISSN n² 2526-8031

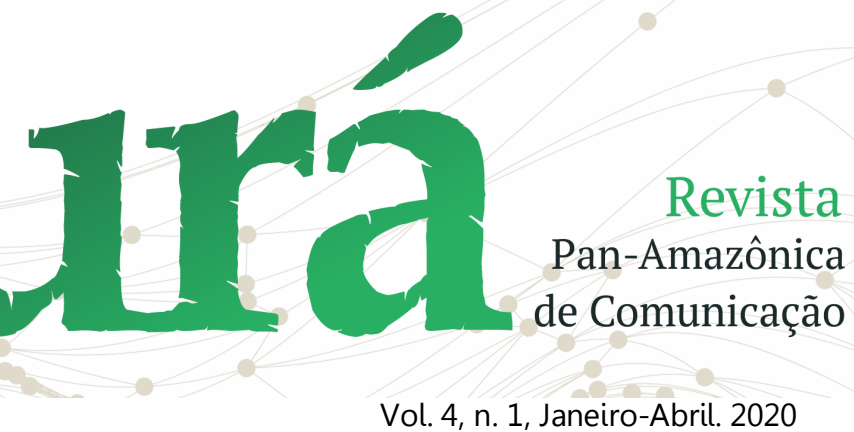

Vol. 4, n. 1, Janeiro-Abril. 2020

DOI: http://dx.doi.org/10.20873/uft.2526-8031.2020v4n1p182

dias. E se debatem nas controvérsias e dilemas.

Eles, que só estão separados por bancadas, vivem o desafio diário do trabalho honesto, do respeito à verdade da atividade jornalística.

\section{CARACTERÍSTICAS E FUNÇÕES DO ASSESSOR DE IMPRENSA}

São diversas as funções que um assessor de imprensa desenvolve dentro da organização. Uma delas, segundo Ferraretto e Ferraretto (2009), é colocar à disposição do assessorado os conteúdos mais adequados para serem desenvolvidos durante as comunicações com as diversas mídias.

Os autores Ferraretto e Ferraretto (2009), destacam que com o passar dos anos a função do assessor foi sendo modificada e que a teoria de encher os formadores de opinião que atuam nas redações de releases e mais releases já não é mais uma das características do assessor dos dias de hoje, que agora se destaca, também, como intermediário que possibilita aos produtores desenvolverem notícias relevantes.

A função do assessor de imprensa é "facilitar a relação entre seu cliente, empresa, pessoa física, entidades e instituições - e os formadores de opinião", cabendo a esse profissional orientar seu assessorado quanto ao que pode ou não interessar aos veículos $e$, portanto, vir a ser notícia. (FERRARETO; FERRARETO, 2009, p. 13).

Os autores acrescentam ainda que, mesmo tendo um bom relacionamento com os meios de comunicação e sempre enviar releases para as redações, o assessor também tem como função a elaboração de press kits, desenvolvimento do serviço de clipagem, mailing list, edição de house organ, entre outros.

Para Mafei (2009), o mercado de trabalho está cada vez mais exigente e busca profissionais com perfis que sejam familiarizados com a realidade. Portanto, assessor deve ser um profissional que trabalhe de forma diferenciada, construindo um perfil o mais adequado à realidade do seu assessorado.

Mafei (2009) ensina que uma das funções do assessor é apresentar as mesmas características de um bom repórter, ou seja, enquanto o repórter corre atrás das fontes buscando informações corretas e que vão ser de interesse público, 0 assessor deve pesquisar incansavelmente para ter boas e 


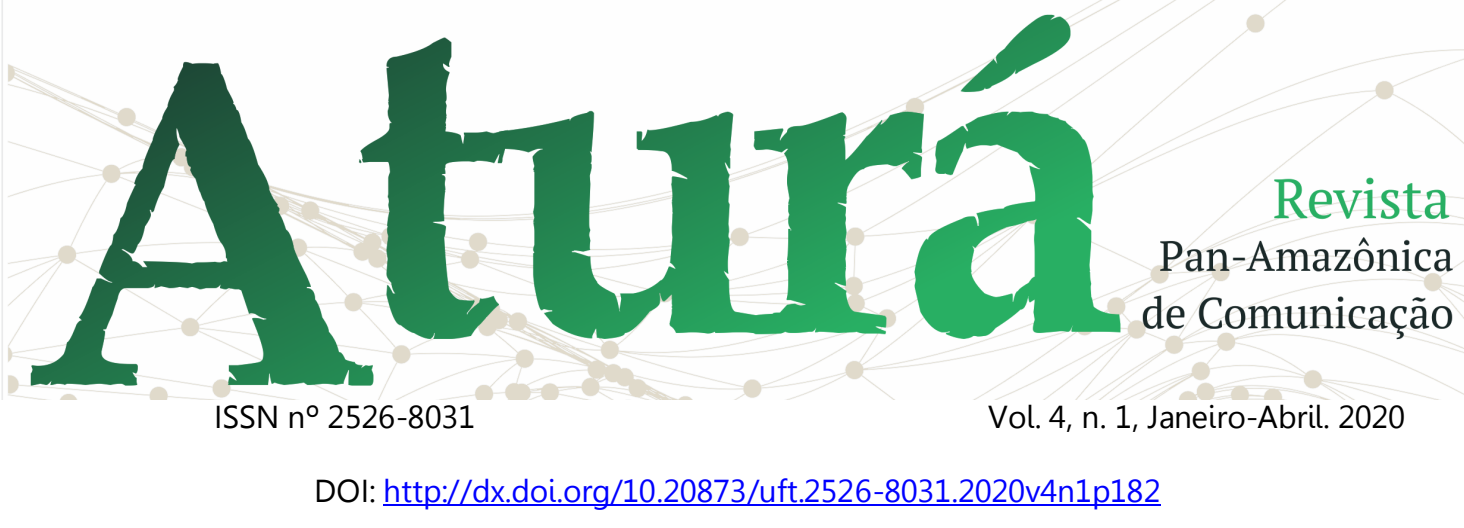

corretas informações sobre seu assessorado e assuntos referentes a ele.

O bom assessor é aquele que estabelece e executa práticas que levam à veiculação de informações corretas. Para tanto, precisa conhecer a produção jornalística, com todas as suas "esquizofrenias". (MAFEl, 2009, p. 26).

É trabalho do assessor de imprensa executar uma das partes que pode ser considerada como a mais complexa dentro da atividade de assessorias que é a mídia espontânea, em que os meios de comunicação tenham interesse na divulgação de assuntos dos assessorados, divulgando-os como de cunho jornalístico. (MAFEI, 2009).

Administrar os momentos de crise nas organizações, sabendo discernir o que deve ser liberado para os meios de comunicação nos momentos certos e o que deve ou não ser colocado como sugestões de pautas são, entre outras, algumas técnicas que o assessor deve saber desenvolver na hora de fazer o trabalho de assessoria, independentemente de onde essa atividade seja desenvolvida. (MAFEI 2009).

Já para Duarte (2003), o trabalho do assessor vai mais além do que o relacionamento com os jornalistas, uma vez que a boa administração da comunicação e das informações para os públicos internos e externos pode ser fundamental para o bom desenvolvimento da organização.

O autor destaca ainda, de forma detalhada, as vantagens quanto ao melhor desenvolvimento da atividade do assessor quando ele faz o acompanhamento das entrevistas participando de perto na hora do desenvolvimento das sonoras, o que the permite observar possíveis erros ou repetição de palavras do assessorado. Duarte (2003) destaca que essa é uma forma de administrar as informações, não deixando que sejam repassadas notícias distorcidas ou que possam comprometer.

A pontualidade na hora das entrevistas ou até mesmo o cumprimento de prazos e o pleno conhecimento sobre a organização e seu assessorado são uma das recomendações fundamentais para esse tipo do trabalho. Duarte (2003) chama a atenção para as tantas armas que o assessor pode usar na batalha de fazer um excelente trabalho, como por exemplo, o apoio de eventos, atendimento à imprensa, avaliação de resultados, bancos de 


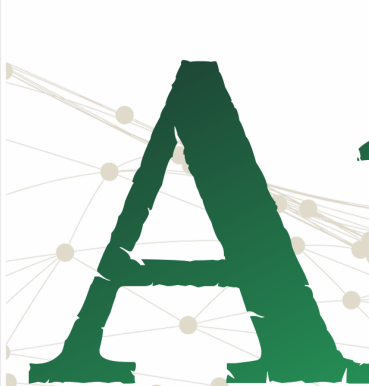

ISSN n² 2526-8031

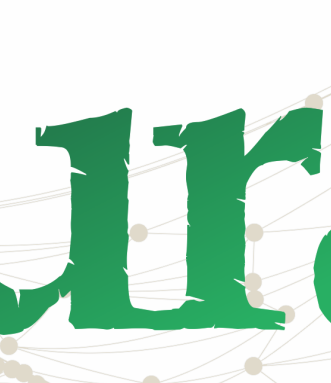

á

Vol. 4, n. 1, Janeiro-Abril. 2020
Revista

Pan-Amazônica

de Comunicação

DOI: http://dx.doi.org/10.20873/uft.2526-8031.2020v4n1p182

dados, brindes, capacitação de jornalistas, análise de noticiário, coletivas entre outras.

$O$ autor deixa claro que $\mathrm{O}$ bom relacionamento, tanto com os pauteiros e repórteres é de extrema importância, pois se torna um momento de trocar ideias, informações, contatos. Ou seja, é naquele momento que 0 assessor vai ter a oportunidade de aumentar o contato com o jornalista, ajudando ainda mais no bom desenvolvimento do trabalho de assessoria de imprensa.

Para Duarte (2003), dentre tantas as ferramentas usadas pelo assessor de imprensa para mandar material noticioso aos jornalistas o release é um dos mais usados por possuir diversos formatos, conforme o momento, $\mathrm{O}$ veículo e a necessidade.

\section{CARACTERÍSTICAS E FUNÇÕES DO PRODUTOR DE TV}

A estrutura de uma redação sempre vai ser a mesma, o que pode mudar é a quantidade e a qualidade dos profissionais existentes. A diferença entre uma bem estruturada e outra menos sempre será o número de jornalistas atuando, pois as atividades sempre serão as mesmas. (CURADO, 2002).

Os cargos e as funções descritos podem ter outros títulos e atribuições ligeiramente diferentes em cada empresa. Entretanto, ainda que seja assim, não se faz jornalismo em televisão sem o cumprimento de todas as tarefas relacionadas. O essencial é a correta distribuição de responsabilidade. (CURADO, 2002, p. 28).

A autora exemplifica as principais funções dentro de uma grande redação, assim classificando-as:

- Diretor Responsável: o profissional que tira quase sempre a dúvidas dos jornalistas quando o assunto é relacionado às editorias, além de orçamentos e até a demissão e contratação de novos profissionais.

- Chefe de redação: considerada a segunda pessoa mais importante dentro de uma redação, é visto como um guia em todas as atividades desenvolvidas dentro da redação, já que ele tem a tarefa de acompanhar o trabalho de repórteres, editores e produtores, além de dar sugestões de pautas e definir os últimos detalhes antes do fechamento do jornal.

- Chefe de reportagem: responsável pelos equipamentos, necessidades de 


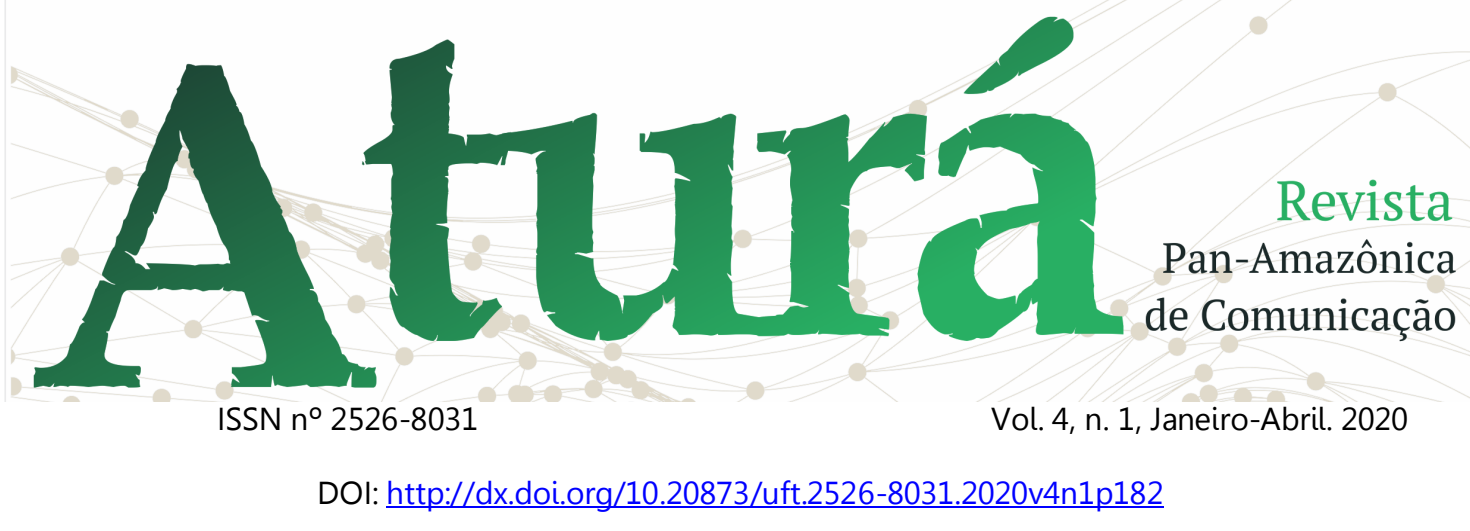

aparelhamentos, além de orientar no desenvolvimento das pautas e no trabalho de produção.

Produtor/pauteiro: o jornalista que produz a reportagem e que, por meio da pauta, orienta - repórter sobre a matéria que será desenvolvida. Marca entrevistas e orienta cinegrafistas sobre a captação de imagens.

Repórter: responsável por ir a campo e colher as informações necessárias para finalização do material jornalístico que irá ao ar. Tem por obrigação também apurar cuidadosamente todas as informações antes que a matéria seja fechada.

Além desses cargos básicos, Curado (2002), acrescenta que as funções desenvolvidas dentro das redações vão muito mais além das citadas acima, sendo realidade nos grandes jornais a existência do repórter local, regional, de rede nacional, correspondente internacional, repórter cinematográfico, produtor de campo, editor chefe, produtor editor, editor de arte, de imagens, âncora, apresentador entre outros.

Sobre o trabalho do produtor, a mesma autora destaca que é um cargo não muito visado e pouco valorizado, mas ele é fundamental para o bom desenvolvimento das reportagens, sendo também um verdadeiro pauteiro que deve ter faro jornalístico e buscar incansavelmente novas informações para serem acrescentadas na pauta. "Numa redação de jornalismo existe um grupo de profissionais responsáveis por reunir um cardápio de informações que poderão de tornar reportagens. O nome do setor é o mesmo que o da sua tarefa: a pauta". (CURADO, 2002, p.40).

Referindo-se ao trabalho dos pauteiros, Duarte (2003), pontua que a importância de uma pauta para a televisão é bem maior do que para os demais veículos de comunicação. Isso porque a retratação dos fatos deve ser mais explorada e numa corrida contra o tempo, qualquer erro, cancelamento ou anulação de pauta pode ser frustrante para os jornalistas de TV, que têm que passar essa notícia por vários processos antes da informação ir ao ar.

É por isso que, na redação de um telejornal, não pode haver espaço para improvisações de última hora. Mudanças ocorrem, é claro, como em qualquer redação jornalística, mas estas não podem fugir ao controle da equipe que comanda a edição final do programa. (DUARTE, 2003, p.117). 


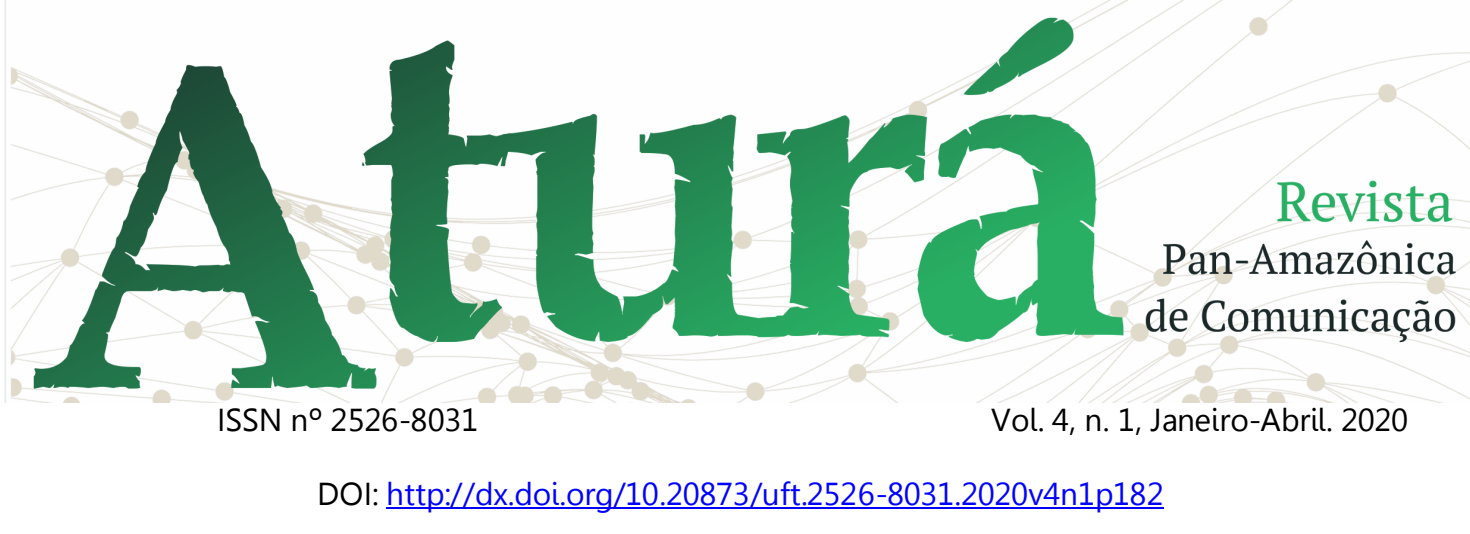

Ainda sobre a estrutura de um telejornalismo, Martins, (acesso em: $27 \mathrm{fev}$. 2012), diz que a atividade jornalismo é composta de várias funções, entre elas está a de produtor que, em boa parte das empresas exerce diversas atividades dentro das redações.

As redações de TV funcionam hoje apoiadas nos ombros desse profissional, que na maioria das vezes é alguém competente que tem de farejar a pauta, entrevistar os personagens antes do repórter e marcar entrevistas. Além de coordenar equipes de cinegrafistas, auxiliar motoristas e repórteres, fazer ronda, sejam em delegacias, lideranças comunitárias ou ministérios. (MARTINS, acesso em: 27 fev. 2012).

De acordo com Roberto Seabra (acesso em: 28 fev. 2012), boa parte do funcionamento de uma redação depende de certo padrão hierárquico, funcionando tudo sobre uma supervisão de um editor-chefe, pois ele é o elo entre a direção do veículo, repórteres e pauteiros.

Cada redação tem suas próprias características, ainda mais quando cada tipo de mídia é diferenciado, porém alguns pontos são imutáveis, primeiro, na redação não é o local onde acontecem as notícias, segundo, uma redação não é o único lugar onde se decide o destino e o formato de determinada notícia. Compreender a diferença entre interesse e importância é o primeiro passo para conseguir entender o funcionamento de uma redação. (SEABRA, acesso em: 28 fev. 2012).

\section{O BOM ASSESSOR PASSA PELAS REDAÇÕES}

Os jornalistas vindos das redações muitas vezes se desenvolvem até melhor nas assessorias do que os que já começaram suas carreiras como assessores. Ao contrário do que muitos pensam, que assessores são apenas os que não deram muito certo dentro das redações, a experiência adquirida dentro de um jornal pode ser fundamental para que ele desenvolva um excelente trabalho de assessoria de imprensa posteriormente (DUARTE, 2003).

$O$ autor acrescenta ainda que o assessor na verdade é um porta-voz ou intermediário entre o seu assessorado e os jornalistas das redações, que veem o trabalho de assessoria como mais uma fonte de informação, enquanto o jornalista assessor precisa do produtor como uma fonte para publicar assuntos de interesse do seu assessorado. Destaca-se que o grande diferencial é a aproximação entre os jornalistas de redações 


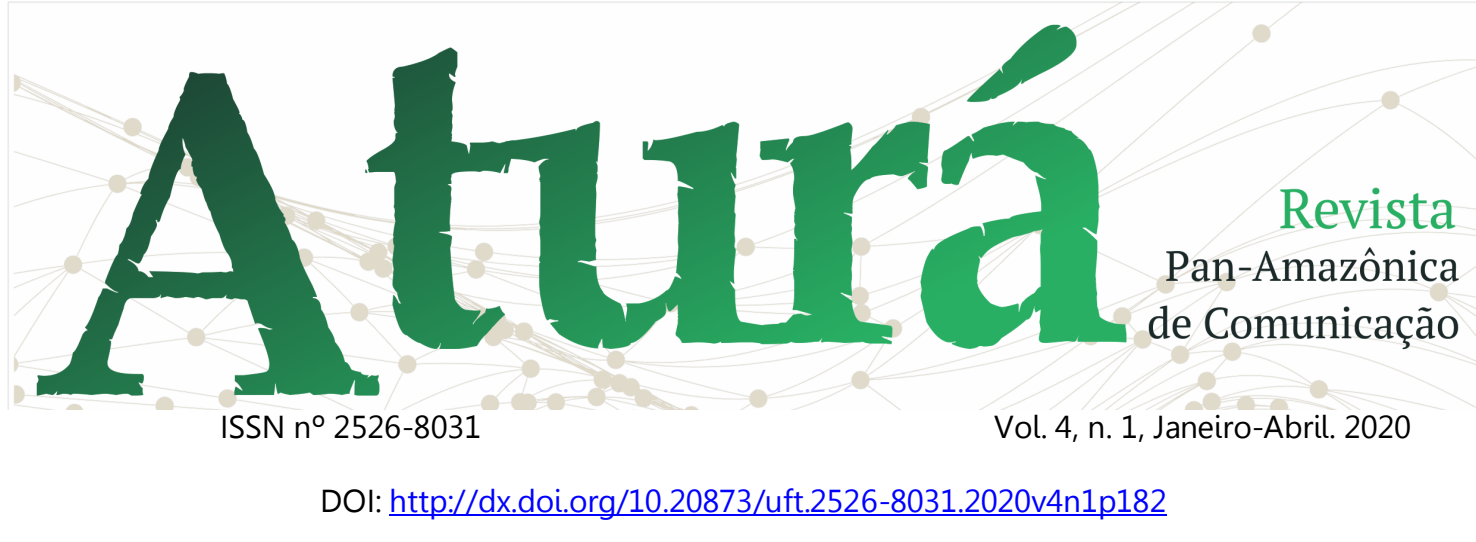

e das assessorias, aproximação essa que é bem sucedida quando o assessor sai de dentro das redações. Duarte (2003), conclui que:

A boa atuação de uma assessoria aumenta a visibilidade pública da organização e pode trazer efeitos mercadológicos e políticos predeterminados, por perceber isso é que, cada vez mais, instituições brasileiras têm interesse em divulgar suas atividades e propostas pelos meios de comunicação buscando influenciar a opinião pública. (DUARTE, 2003, p. 90).

Além do assessor de imprensa ser um intermediário entre seu assessorado e os jornalistas dos diversos meios de comunicação, ele também orienta sobre o que deve ou não virar notícia. (FERRARETTO; FERRARETTO, 2009). Para Mafei (2009), é essencial que além do assessor de imprensa ser um jornalista de formação ele também tenha passado por um uma boa redação ou por grandes redações, pois com isso ele saberá diferenciar o que realmente vale ser notícia ou não.

Mas se o profissional não tiver tido oportunidade de passar por uma redação (por conta da crise de emprego na indústria da comunicação de massa), deverá ter perspicácia para entender como funciona o sistema de produção de notícias. (MAFEl, 2009, p. 44).

A autora explica que não apenas nas literaturas ele vai saber distinguir o que é notícia ou não, mas, sim, na experiência que ele teve nas ruas.

\section{O ASSESSOR E AS NECESSIDADES DO}

\section{ASSESSORADO}

Referindo-se às necessidades do assessorado, Mafei (2009), explica que não importa para quem 0 assessor esteja desenvolvendo a atividade de assessoria de imprensa, ele deve fazer um trabalho excelente, pois os assessorados, provenientes de diversos segmentos desde órgãos públicos até entidades privadas, querem é a aprovação da opinião pública referente aos assuntos de seus interesses.

Essa realidade pode ser estendida a todos os assessorados, independentemente de ser uma grande instituição financeira, o dono de uma única loja de café, uma ONG de defesa do meio ambiente ou uma associação popular de mães. O que todos querem é que a percepção pública de suas atividades contadas pela imprensa corresponda ao que eles realmente são. $\mathrm{E}$ para tanto que o assessor deve trabalhar. (MAFEl, 2009, p. 55). 


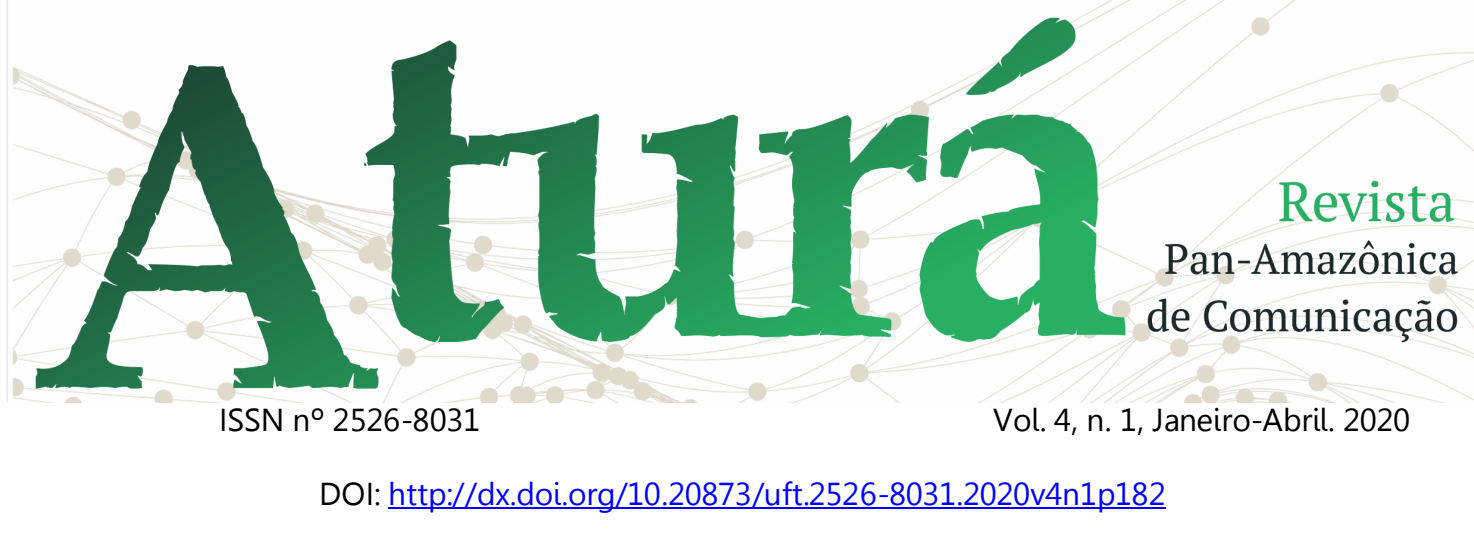

Já para Milhomem (2003), uma das necessidades do assessorado é que o seu assessor tenha autonomia para administrar os conflitos, demonstrar opções para que um problema seja resolvido, além de estar sempre ligado em tudo o que está acontecendo, sejam eventos nacionais ou internacionais.

Além disso, o assessorado também alimenta a expectativa de que o seu assessor se esforce para fortalecer a boa imagem da empresa perante a opinião pública, sem deixar de estar sempre construindo uma imagem positiva não só com relação à opinião pública, mas também aos públicos internos. (MILHOMEM, 2003).

É fácil encontrar assessores que se ocupem mais de uma dessas funções. Costuma ser forte a pressão de alguns dirigentes para que sua atuação obtenha destaque na mídia. Querem visibilidade máxima. Gostam de ver seu nome à frente de qualquer êxito da instituição. (MILHOMEM, 2003, p. 316).

\section{PUBLICAÇÃO DO RELEASE: ENTRE A APURAÇÃO E O DEADLINE}

Duarte (2003) explica que é impossível um jornalista na sua busca diária por notícias, apurar informações de interesse público nas instituições ou organizações, vendo-as se são realmente verdadeiras ou não, isso seria uma perda de tempo, já que tempo é um vilão para quem trabalha com jornalismo, seja qual for à organização.

Para o autor, o trabalho do assessor dentro desses órgãos é fundamental para que sejam geradas informações que interessem aos jornalistas, fazendo eles o trabalho de repórter, que é apurar e tornar disponível o que é considerado com material jornalístico e isso se dá através da publicação do release.

Release pode ser entendido como material jornalístico distribuído aos jornalistas para servir de pauta, orientação ou ser veiculado completo ou parcialmente, de maneira gratuita. É uma proposta de assunto, um roteiro, uma sugestão de pauta, mas do ângulo de quem o emite. (DUARTE, 2003, p. 288).

Duarte (2003) relata que a função do release é muito importante, já que ele é considerado um material jornalístico, por isso o assessor ganha crédito no conceito do jornalista das redações quando seu release contém informação de credibilidade, verdadeira e que as informações norteiem praticamente todo o processo de produção do 


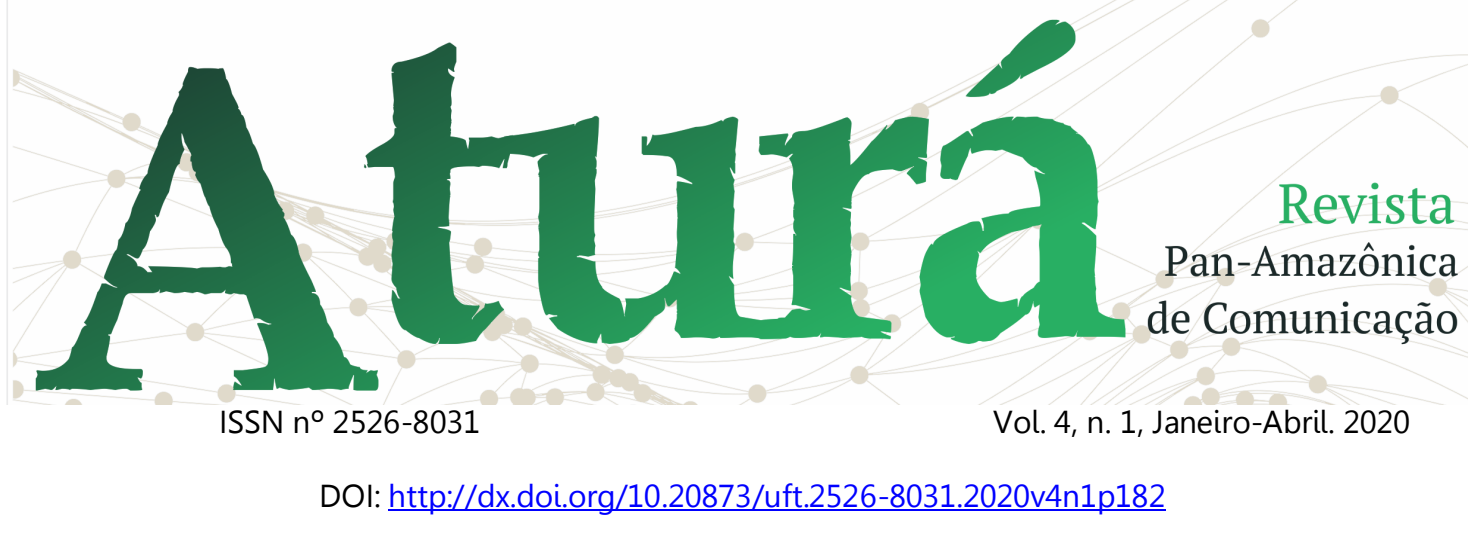

telejornal ou em qualquer outro meio de comunicação.

A regularidade do recebimento de informações de qualidade, mesmo que por release, faz com que o jornalista estabeleça um conceito pessoal sobre a organização, saiba sobre sua atuação e potencial de pauta - o que será importante em qualquer ocasião. (DUARTE, 2003, p. 288).

A publicação de releases além de ser importante nas redações também ajuda a diminuir a demanda de atividades dentro de um jornal, já que a correria para o fechamento das notícias, em muitos casos, até impede que o jornalista faça uma apuração mais cuidadosa da informação.

Para isso, os releases devem ser cada vez mais eficientes e com grande responsabilidade, pois precisam ser confiáveis dentro das redações já que são constituídos de informações prontas para serem publicadas, trazendo assim um maior conforto no momento da apuração, diminuído o processo de produção, mesmo que na maioria dos casos mostrem apenas um ponto de vista da informação. (DUARTE 2003).
O bom assessor de imprensa apresenta a informação de forma embalada, prêt-aporter, pronta para uso ou, pelo menos, para facilitar o trabalho na redação. Ele sabe que jornalista normalmente atua sob pressão de prazos, da concorrência e dos superiores e possui complicados mecanismos de avaliação e seleção do que será notícia e até tem dificuldades de explicar os critérios que determinam as escolhas, os chamados valores notícia. (DUARTE, 2003, p. 290).

Segundo o autor, quando um release é de qualidade e confiável, vai ser muito difícil ele não se tornar uma pauta que servirá para veiculação em determinado meio de comunicação, já que isso diminuirá muito o desenvolvimento de uma reportagem antes que esteja pronta para veicular. Por isso, o autor destaca a importância do release ser bem apurado pelos assessores e que seja bem discutido e estudado antes de ser encaminhados aos e-mails dos jornalistas.

Discutido às vezes palavra por palavra, vírgula por vírgula com a diretoria de uma empresa antes de ser enviado, pode ser deletado ou jogado fora imediatamente no lixo (a famosa cesta seção) ao chegar à redação. Às vezes, redigido despretensiosamente, pode transformarse sob a análise de um editor atendo e sagaz, em manchete no dia seguinte. (DUARTE, 2003, p. 291). 


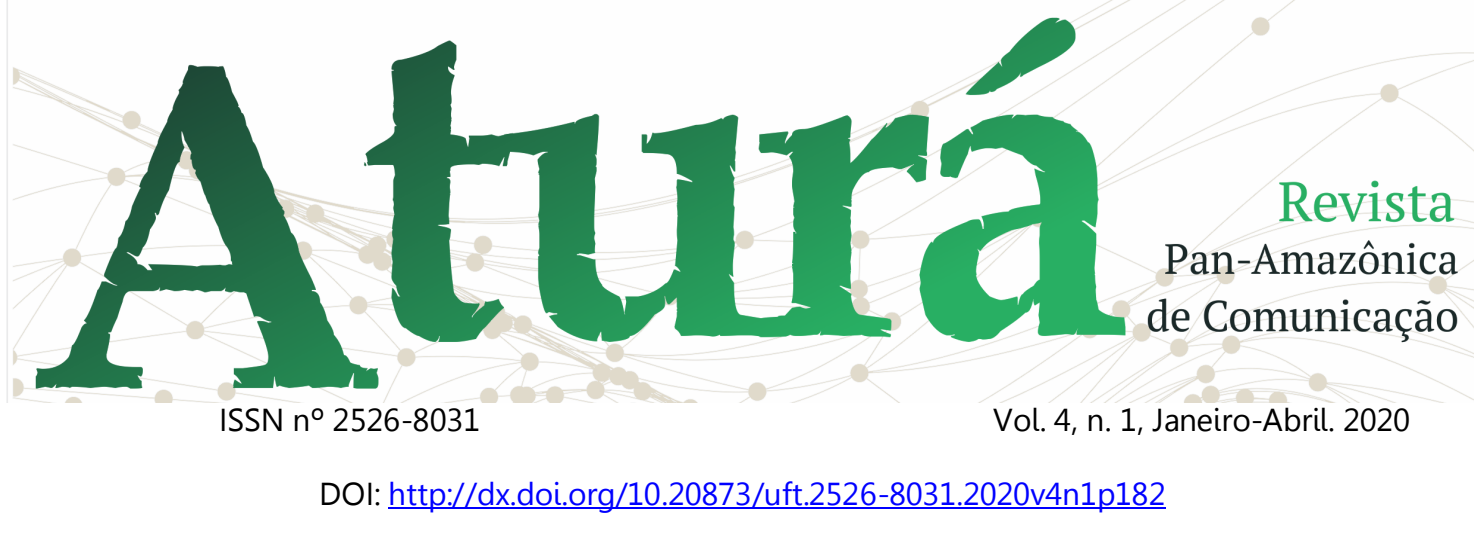

O release, ainda segundo Duarte (2003), é uma fonte muito importante para a veiculação de uma notícia, apesar de ser oferecido da forma que melhor atenda aos interesses do assessor. E para isso o tempo é primordial para essa divulgação tanto dentro das redações como nas assessorias até o seu deadline em ambas as partes.

Jornalistas não costumam questionar se as informações são verdadeiras; eles confiam, até porque o capital de credibilidade é o mínimo que um assessor pode ter. A veracidade do release é a pedra angular que sustenta sua proliferação ao longo dos anos, apesar das evidentes limitações que possui e das restrições que a ele são feitas (DUARTE, 2003, p. 291).

\section{UMA RELAÇÃO DE MÃO DUPLA, UMA QUESTÃO DE ÉTICA}

A mídia, em especial a televisiva, é a grande responsável por influenciar e formar a opinião do público. A grande massa tem a convicção de que tudo o que é veiculado nos meios de comunicação é uma verdade absoluta, por isso é preciso ter ética e muita responsabilidade no que está sendo divulgado pelos jornalistas. (CHRISTOFOLETTI, 2008).
No jornalismo, a ética é mais que rótulo, que acessórios. No exercício cotidiano da cobertura dos fatos que interessam à sociedade, a conduta ética se mistura com a própria qualidade técnica de produção do trabalho. Repórteres, redatores e editores precisam dominar equipamentos e linguagens, mas não devem se descolar de seus comprometimentos e valores. Podem tentar suspender suas opiniões em certos momentos, mas, se por acaso esquecerem suas funções e suas relações com o público, vão colocar tudo a perder. (CHRISTOFOLETTI, 2008, p. 11).

O autor acrescenta ainda que ética é uma questão moral, ou seja, os valores morais vindos de muito tempo, ainda quando a sociedade, formada em pequenos grupos, decidia o que se podia fazer ou não, o que era certo ou errado.

Isso deve estar presente onde o trabalho de jornalista esteja sendo desenvolvido. A ética na produção de uma notícia é uma preocupação desde os bancos da faculdade, onde são ditadas as regras sobre tudo o que se deve fazer: como a importância de ouvir os dois lados de uma história; o perigo de expor uma pessoa ainda suspeita como acusada entre outras questões que norteiam e cercam a vida dos formadores de opinião. 


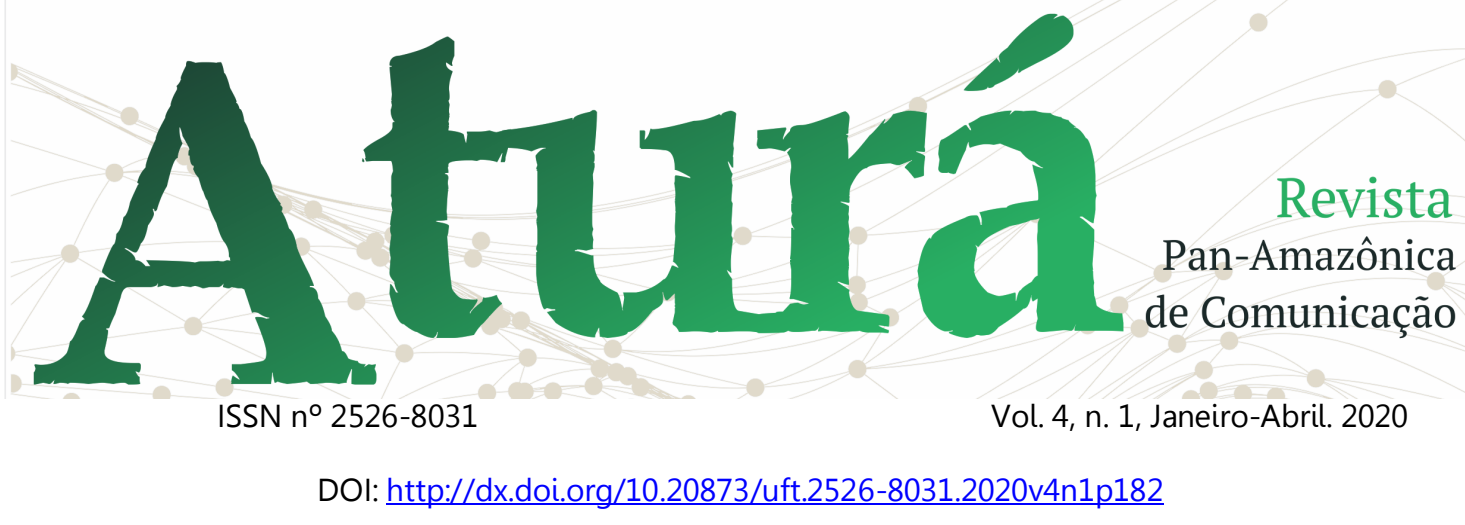

Devido a esses fatores, Christofoletti (2008) destaca que a ética, que não é apenas vista em sua formação acadêmica, mas desde a criação familiar, é fundamental onde o trabalho esteja sendo executado, seja ele qual for.

Já para Bucci (2000), o jornalismo é uma profissão de conflitos, onde a imprensa deve ser um verdadeiro órgão fiscalizador que vive em constante diálogo entre as instituições sejam elas públicas ou não, questionando tudo o que é de interesse público.

O autor diz que esse diálogo é um verdadeiro trabalho de apuração detalhada da informação na hora de desenvolver uma notícia. $\mathrm{O}$ autor defende ainda que para fazer esse trabalho de fiscalizar principalmente os assuntos públicos, é preciso que o jornalista seja ético em todo o seu trabalho. Mas, de acordo com o autor, infelizmente não é isso o que acontece, o repórter pode ser o melhor e mais competente profissional que busca fazer um trabalho ético e imparcial, mas se a empresa onde ele trabalha é paga para tratar apenas dos interesses que certa instituição esteja fazendo, ele nunca vai poder desenvolver $\circ$ verdadeiro trabalho do jornalista, afastando-se assim totalmente de um trabalho ético e prejudicando a sociedade. E acrescenta: "De que adiantam equipes de repórteres de fino trato se os donos de rede de televisão põem a emissora a serviço do candidato a presidente da República, distorcendo os fatos?". (BUCCl, 2000, p. 11).

Chagas (2003) também alerta para a forma como a ética é interpretada por alguns proprietários dos meios de comunicação, ou seja, tudo o que lhes interessa e que traga resultados financeiros. Nesse entendimento, por mais que uma empresa esteja com a melhor equipe, tanto técnica como eticamente, não vai adiantar muito fazer o verdadeiro trabalho jornalístico já que ética em muitos meios de comunicação é o dinheiro.

O autor acrescenta que os empresários da comunicação não estão preocupados se notícia é a retratação verdadeira de um fato, pois os interesses financeiros e os rendimentos dentro dos jornais é o que importa, mesmo que o trabalho esteja sendo desenvolvido de forma imparcial. "Há quem julgue ser o enriquecimento dos proprietários de jornais, revistas, emissoras de rádio e televisão. Para eles, o jornalismo é um negócio 


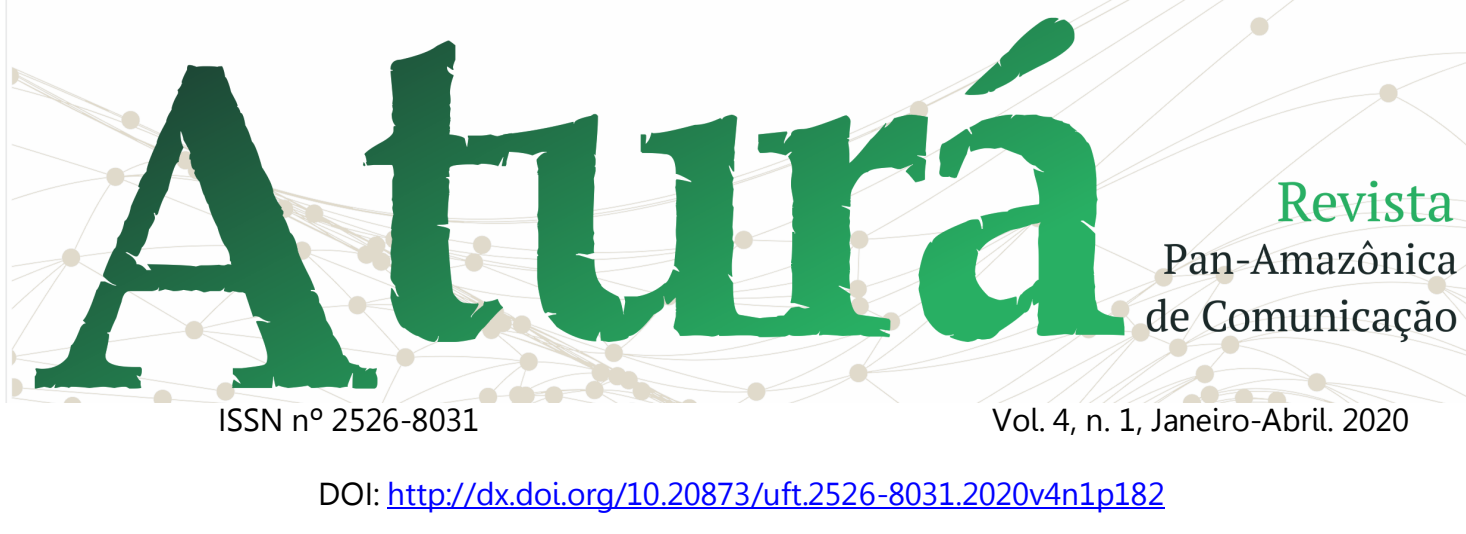

e a ética deve servir a seus propósitos". (CHAGAS, 2003, p. 211).

\section{CONCLUSÃO}

O trabalho dos jornalistas em suas diversas funções tem sido cada vez mais estudado nos dias de hoje. O bom relacionamento com os colegas de profissão é o diferencial no mercado e o que vem chamando a atenção seja onde esse trabalho for desenvolvido.

Com os produtores, repórteres e assessores de imprensa não é diferente; de um lado, na redação, a correria dos produtores e repórteres é uma rotina diária e normal que deve ser bem administrada por esses jornalistas. Nas assessorias de imprensa, da mesma forma. É imprescindível saber lidar com os companheiros, conhecer e se adaptar à realidade dos seus assessorados e dos órgãos e instituições onde o trabalho de assessoria está sendo desenvolvido devem ser características desses profissionais.

Enquanto nos jornais, os repórteres buscam fechar suas edições com matérias de interesse da sociedade, analisando releases, apurando informações, buscando algo diferente para que a sociedade tenha notícias novas, de qualidade e com diferencial, os assessores de imprensa buscam incansavelmente levar e proporcionar a esses formadores de opinião, assuntos sobre seus assessorados que possam gerar uma boa notícia e servir de interesse público, ajudando também na demanda de informação de um telejornal.

Ou seja, nos dois lados da bancada atuam profissionais que conhecem o que é de interesse da sociedade e que trabalham com um só objetivo, que é gerar informação de qualidade e que agregue valor ao conhecimento de cada cidadão.

Mediante tantas correrias, estresses e interesses pessoais, há um fator que é primordial dos dois lados, que é justamente o bom relacionamento, o contato diário entre assessores, assessorados, produtores, repórteres entre outros.

Além disso, explorar as ferramentas de trabalho, que não são poucas e ser o diferencial no mercado de trabalho é o que vai determinar os rumos de cada profissional e a empresa no qual ele trabalha, e isso só é possível através de um bom trabalho e da preocupação em manter um bom relacionamento entre eles. 


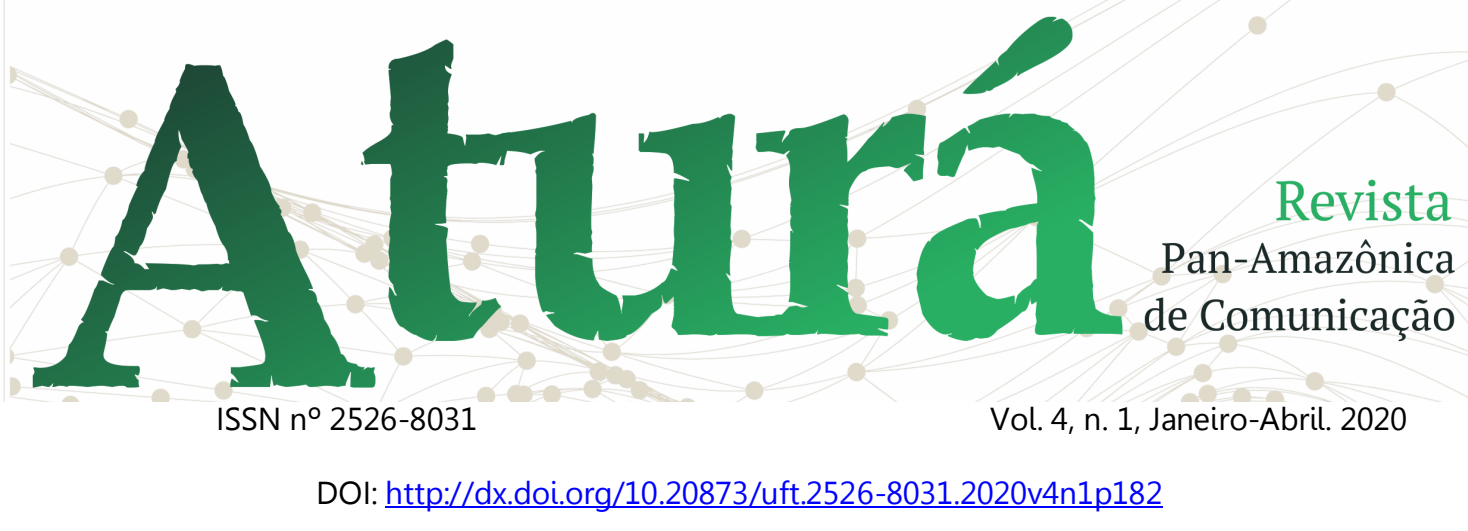

\section{REFERÊNCIAS}

ALVES, E. J.; SILVA, B. D. DA; SILVA, R. DA S. DA. MAPEAMENTO DOS ESTUDOS SOBRE A FORMAÇÃO DE PROFESSORES NO ÂMBITO DO PROCESSO DE BOLONHA EM PORTUGAL. Revista Observatório, v. 3, n. 6, p. 248-273, 1 out. 2017.

ANDREATTA-DA-COSTA, L.; CASTILHOS, A. DA C. CONTRIBUIÇÕES DO FACEBOOK PARA A ALFABETIZAÇÃO MATEMÁTICA NO $3^{\circ}$ ANO DO ENSINO FUNDAMENTAL. Revista Observatório, v. 3, n. 5, p. 274-300, 1 ago. 2017. BAPTAGLIN, L. A.; CHIERENTIN SANTI, V. J. AS INTERVENÇÕES ARTÍSTICAS URBANAS NO CIRCUITO DA ARTE EM RORAIMA E O POTENCIAL COMUNICATIVO DOS SABERES ARTÍSTICOS AMAZÔNICOS. Revista Observatório, v. 4, n. 4, p. 615-637, 29 jun. 2018.

BUCCl, Eugênio. Sobre ética e imprensa. São Paulo: Companhia das Letras, 2000.

CHAGAS, Carlos. Agir ético dentro e fora das assessorias de imprensa. In: DUARTE, Jorge. Assessoria de imprensa e relacionamento com a mídia. São Paulo: Atlas S. A. - 2003.

CHRISTOFOLETTI, Rogério. Ética no jornalismo. São Paulo: Contexto, 2008.
CURADO, Olga. A noticia na TV: o dia-a-dia de quem faz telejornalismo. Sao Paulo: Alegro, 2002.

DUARTE, Jorge(Org.). Assessoria de imprensa e relacionamento com a mídia: teoria e técnica. 2. ed. São Paulo: Atlas, 2003.

ELHAJJ, M.; ESCUDERO, C. WEBDIÁSPORA: Migrações, TICs e memória coletiva. Revista Observatório, v. 2, n. 5, p. 334-363, 25 dez. 2016.

EVANGELISTA， F.; MARTINS，K. D.; ANGELINI, M. F. C.; ROCHA, M. J. F. SOCIEDADE DO CONHECIMENTO: O uso das TIC por docentes e as novas articulações de saberes educacionais no sudeste do Pará. Revista Observatório, v. 5, n. 5, p. 188-208, 1 ago. 2019. FERRARETTO, Elisa Kopplin; FERRARETTO, Luiz Artur. Assessoria de Imprensa: teoria e prática. 5.ed. São Paulo: Summus, 2009.

GALLERT, A. Z.; TACCA, M. C. V. R. ESCOLHA PROFISSIONAL E PERSPECTIVAS DE FUTURO NA DOCÊNCIA: uma análise a partir da subjetividade dos professores. Revista Observatório, v. 2, n. 4, p. 419-441, 30 out. 2016. 


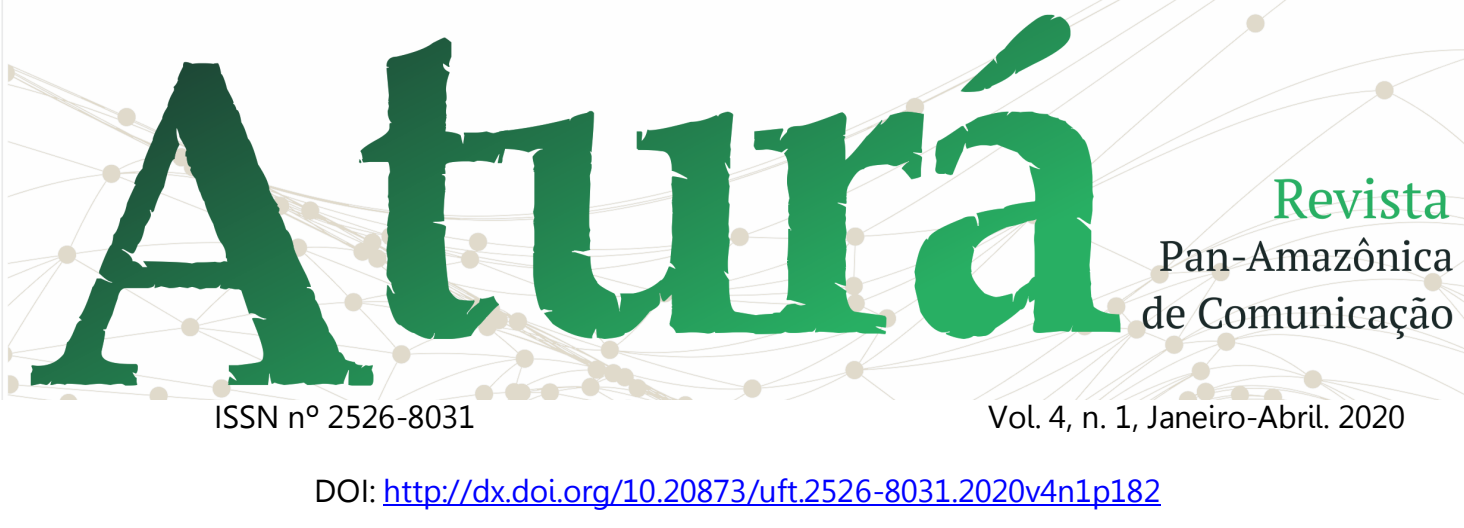

LOPES, P.; PEREIRA, S.; MOURA, P.; CARVALHO,

A. Avaliação de competências de literacia mediática: o caso português. Revista Observatório, v. 1, n. 2, p. 42-61, 8 dez. 2015. LUCENA, S.; OLIVEIRA, A. A. D. DIÁRIO ONLINE NA INICIAÇÃO À DOCÊNCIA: uma experiência de pesquisa multirrreferencial. Revista Observatório, v. 5, n. 1, p. 158-181, 14 jan. 2019.

MACHADO, L. S.; COSTA, T. K. DE L.; MORAES, R. M. DE. MULTIDISCIPLINARIDADE E O DESENVOLVIMENTO DE SERIOUS GAMES E SIMULADORES PARA EDUCAÇÃO EM SAÚDE. Revista Observatório, v. 4, n. 4, p. 149172, 29 jun. 2018.

MARTINEZ, M. Reflexões sobre Jornalismo e História Oral: um campo com mais convergências do que dissonâncias. Revista Observatório, v. 2, n. 1, p. 75-91, 1 maio 2016. MAFEl, Maristela. Assessoria de imprensa: como se relacionar com a mídia.

MARTINS, Victor. Estrutura de um Telejornalismo. Disponível em: $<$ http://manualdosfocas.com.br >. Acesso em: 27 fev. 2012.

MELO, A. S. E. ENQUADRAMENTO HISTÓRICO LEGAL DO PROCESSO DE BOLONHA E O SEU IMPACTO NO SISTEMA DE ENSINO SUPERIOR
PORTUGUÊS. Revista Observatório, v. 3, n. 6, p. 75-141, 1 out. 2017.

MILHOMEM, Luciano. Relacionamento Assessor/Assessorado: entre tapas e beijos. In: DUARTE, Jorge. Assessoria de imprensa e relacionamento com a mídia. São Paulo. Atlas, 2003.

MIRANDA-PINTO, M. S.; MONTEIRO, A. F.; OSÓRIO, A. J. POTENCIALIDADES E FRAGILIDADES DE ROBÔS PARA CRIANÇAS EM IDADE PRÉ ESCOLAR: 3 A 6 ANOS. Revista Observatório, v. 3, n. 4, p. 302-330, 1 jul. 2017. MOIO, I.; ALCOFORADO, L.; VIEIRA, C. C. A DECLARAÇÃO DE BOLONHA E O REFORÇO DA ABERTURA DO ENSINO SUPERIOR A NOVOS PÚBLICOS: perceções de pessoas adultas que frequentam a Universidade de Coimbra. Revista Observatório, v. 3, n. 6, p. 169-201, 1 out. 2017.

MOTA, L. C. M. DE A.; FERREIRA, A. G. A FORMAÇÃO DE PROFESSORES EM PORTUGAL NO QUADRO DO ESPAÇO EUROPEU DE ENSINO SUPERIOR. Revista Observatório, v. 3, n. 6, p. 38-74, 1 out. 2017.

NEIVA, I. C.; AUGUSTO, A. Comunicólogo que brinca comunica mais?. Revista Observatório, v. 1, n. 1, p. 43-62, 30 set. 2015. 


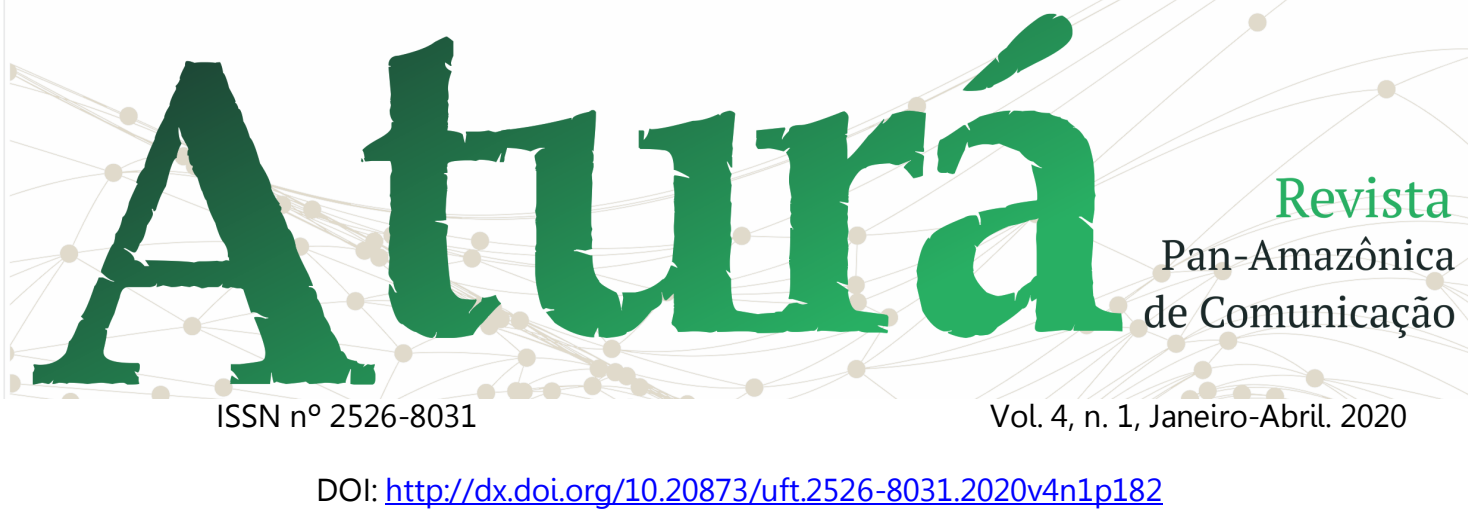

NUNES, S. G.; PORTO JUNIOR, F. G. R.; MORAES, N. R. DE. CONHECIMENTO E ORGANIZAÇÃO: indicativos pós-Bolonha de uma sociedade em construção. Revista Observatório, v. 3, n. 6, p. 338-353, 1 out. 2017. PINHO, M. J. DE. UNIVERSIDADE E CRISE INSTITUCIONAL: perspectivas de uma formação humana. Revista Observatório, v. 3, n. 6, p. 274-315, 1 out. 2017.

PORTO JUNIOR, F. G. R.; MORAES, N. R. DE. FORMANDO PESQUISADORES PÓSBOLONHA EM PORTUGAL: relações entre a formação de graduação e o campo da pesquisa/investigação. Revista Observatório, v. 3, n. 6, p. 202-228, 1 out. 2017.

REIS, E. G. DOS. O ENSINO SUPERIOR EM CABO VERDE E OS DESAFIOS DO PROCESSO DE BOLONHA. Revista Observatório, v. 3, n. 6, p. 142-168, 1 out. 2017.

ROCHA, J. D. T.; NOGUEIRA, C. DA R. M. FORMAÇÃO DOCENTE: uso das tecnologias como ferramentas de interatividade no processo de ensino. Revista Observatório, v. 5 , n. 6, p. 578-596, 1 out. 2019.

ROCHA, J. D. T.; NOGUEIRA, C. DA R. M.; SOUSA, J. L. DOS S.; SOUSA, G. R. DE. PRÁTICAS PEDAGÓGICAS CURRICULARES: uso das tecnologias na contemporaneidade. Revista Observatório, v. 4, n. 5, p. 673-694, 1 ago. 2018. ROSA, T. M. O.; SILVA, L. H. O. DA; SILVA, E. DA. EXPERIÊNCIAS DE ESTÁGIO SUPERVISIONADO NUM CURSO DE LICENCIATURA EM LETRAS: sentidos e interações nos espaços de formação. Revista Observatório, v. 4, n. 5, p. 487-511, 1 ago. 2018.

SANTOS, E.; MARTINS, V. CIBERVÍDEOS E MULTILETRAMENTOS NA EDUCAÇAO ONLINE. Revista Observatório, v. 4, n. 5, p. 231262, 1 ago. 2018.

SANTOS, J. S. DOS; DA SILVA, E. P.; PEREIRA, I. A. C. BENEFÍCIOS PEDAGÓGICOS DO USO DE EQUIPAMENTOS CELULARES EM SALA DE AULA. Revista Observatório, v. 4, n. 5, p. 536556, 1 ago. 2018.

SANTOS, J. S. DOS; MACEDO, M. DE L. L. PEDAGOGIA DA ALTERNÂNCIA: teoria e prática na construção do conhecimento. Revista Observatório, v. 3, n. 4, p. 581-602, 1 jul. 2017.

São Paulo: Contexto, 2009.

SEIXAS, L. VALORES NOTÍCIA: uma proposta de análise. Revista Observatório, v. 4, n. 4, p. 334-366, 29 jun. 2018.

SEABRA, Roberto. Estrutura de uma Redação. Disponível

em: 


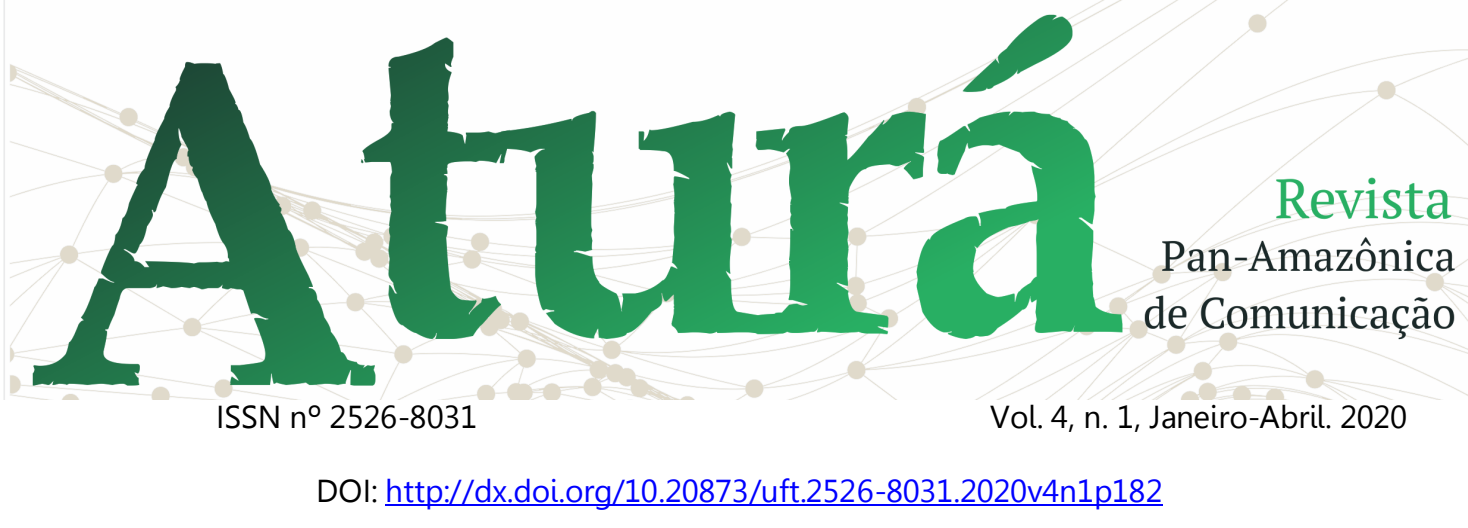

<http://sobresites.com/jornalismo Acesso em

o paradigma pulsional. Revista Observatório, >.: 28 fev. 2012.

SILVA, B. D. DA; ALVES, E. J.; PEREIRA, I. C. A. v. 1, n. 2, p. 136-155, 8 dez. 2015.

DO QUADRO NEGRO AO TABLET: Desafios da docência na era digital. Revista Observatório, v. 3, n. 3, p. 532-560, 1 maio 2017.

SILVA, B. D.; SARTORI, A. S.; MARTINI, R. G. AS TECNOLOGIAS DE INFORMAÇÃO E TEIXEIRA, l.; DA SILVA, V. C.; MARTINS, J. L. A CONVERGÊNCIA MIDIÁTICA E AS TECNOLOGIAS MÓVEIS PÓS-BOLONHA: NOVAS PRÁTICAS SOCIAIS. Revista Observatório, v. 3, n. 6, p. 229-247, 1 out. 2017. COMUNICAÇÃO COMO AGENTES DE INTEGRAÇÃO DO CURRÍCULO COM A GLOCALIDADE. Revista Observatório, v. 3, n. 4, p. 387-406, 1 jul. 2017.

SILVEIRA JUNIOR, P. M. DA. Teoria, conhecimento e pragmática da comunicação: VILAS BOAS, F. S. DE O.; MUNIZ, D. M. S. ENTRE TRAJETÓRIAS E HISTÓRIAS: a formação do professor-leitor. Revista Observatório, v. 4, n. 5, p. 206-230, 1 ago. 2018.

TREVISAN, M. K.; DE PRÁ, E. B.; GOETHEL, M. F. Meme: intertextualidades e apropriações na Internet. Revista Observatório, v. 2, n. 1, p. 277 298, 1 maio 2016. 